\title{
Quantitative Assessment of Anguina sp. and Rathayibacter rathayi in Dactylis glomerata Seed Production Fields in Oregon and Estimates of Yield Loss
}

\author{
Steve C. Alderman, United States Department of Agriculture-Agricultural Research Service, National Forage Seed \\ Production Research Center, and Cynthia M. Ocamb, Department of Botany and Plant Pathology, Oregon State \\ University, Corvallis, 97331, and Mark E. Mellbye, Oregon State University, Linn County Extension, Albany 97321
}

\begin{abstract}
Alderman, S. C., Ocamb, C. M., and Mellbye, M. E. 2005. Quantitative assessment of Anguina sp. and Rathayibacter rathayi in Dactylis glomerata seed production fields in Oregon and estimates of yield loss. Plant Dis. 89:1313-1316.

Anguina sp. is a nematode that infests the inflorescence of orchardgrass and forms galls that replace the seed. Anguina sp. is also a vector of the bacterial pathogen Rathayibacter rathayi, which causes galls or gummosis in orchardgrass (Dactylis glomerata) panicles. The percentage of orchardgrass panicles infected or percentage of seed loss from Anguina sp. or R. rathayi in five commercial orchardgrass seed-production fields in Oregon during 2003 and 2004 was determined. The percentage of panicles with Anguina sp. ranged from 9 to $24 \%$, although the percentage of seed replaced by Anguina sp. was less than $0.2 \%$. The number of galls per panicle ranged from 1 to 29 . However, more than $50 \%$ of Anguina-infested panicles contained only a single Anguina gall and few panicles had eight or more galls. The percentage of panicles with $R$. rathayi ranged from 3 to $27 \%$. Percentage of seed loss from $R$. rathayi ranged from 0.1 to $7.3 \%$. Seed loss in orchardgrass seed-production fields assessed for both Anguina sp. and $R$. rathayi was found to be as great as $8 \%$. The number of Anguina galls remaining in fields following harvest ranged from 0 to 40 per square meter.
\end{abstract}

Additional keywords: bacterial head blight, Rathay's disease, seed gall, yellow berry

Orchardgrass (Dactylis glomerata L.) is an important forage grass grown for seed in the Willamette Valley, OR. The nematode Anguina sp. and the bacterium Rathayibacter rathayi are important pathogens that impact the orchardgrass seed industry directly through seed loss or indirectly through prevention of export due to their presence in seed shipments.

The Anguina sp. that infests orchardgrass is undescribed, but it is known to be distinct from Anguina agrostis, a common seed gall nematode of Agrostis spp. in Oregon (8). The nematodes invade the immature ovary, replacing the seed with dark purple galls that can contain as many as 2,000 nematode juveniles when mature, which coincides with maturity of orchardgrass seed $(1,12)$. However, unlike the common bentgrass nematode, $A$. agrostis, which causes characteristic elongation of glumes, lemma, and palea (4), the orchardgrass nematode causes no morphological change to the lemma, palea, or

Corresponding author: S. Alderman

E-mail: aldermas@onid.orst.edu

Accepted for publication 15 July 2005 .

DOI: 10.1094/PD-89-1313

This article is in the public domain and not copyrightable. It may be freely reprinted with customary crediting of the source. The American Phytopathological Society, 2005 glumes, and there is no obvious change in appearance of infected plants (1). Thus, detection of Anguina sp. in orchardgrass is difficult. Development of a scarifier to remove lemma and palea from seed provided a means to quantify Anguina sp. galls in seed samples (1). In postharvest samples of orchardgrass seed in 2000, Anguina sp. and $R$. rathayi were found in 40 and $48 \%$ of samples, respectively (1). However, the preharvest population density of Anguina sp. within seed-production fields and proportion of galls returned to the field during harvest are unknown. In addition, it is not clear what impact $A n$ guina sp. has on seed yield in orchardgrass.

The genus Anguina is a well-known vector of Rathayibacter spp. $(3,9,10,14)$. $R$. rathayi is an important panicle-infecting bacterium of orchardgrass in Oregon $(1,7)$. Cells of Rathayibacter spp. in soil that contact Anguina spp. during their migration from galls to plants adhere to the nematode cuticle and are carried into the plant with the nematode. Bacteria that proliferate before gall initiation form a yellow gummosis and those that proliferate after that stage kill the nematode and result in yellow, bacterially colonized galls $(1,11)$. In orchardgrass, the bacterial growth is often extensive, resulting in a yellow gummosis of the panicle that envelops a portion of or the entire panicle. There are no seed produced in florets cov- ered by the viscous exudate. The gummosis is most pronounced at head emergence through flowering. The disease is commonly referred to as Rathay's disease, yellow berry, or bacterial head blight. However, quantitative estimates of yield reduction in orchardgrass infected with $R$. rathayi and its vector Anguina sp. are lacking.

The objectives of this study were to (i) assess the preharvest level of Anguina sp. within commercial orchardgrass fields, (ii) estimate the number of galls remaining in the field after harvest, and (iii) estimate yield loss in orchardgrass from Anguina sp. and $R$. rathayi infection.

\section{MATERIALS AND METHODS}

All samples were collected in 2003 and 2004 from each of five orchardgrass fields (cv. Potomac) with a history of Anguina sp. or $R$. rathayi. Fields were located between Albany and Tangent, OR. All fields were in production longer than 3 years and the same fields were sampled in 2003 and 2004.

Preharvest estimates of Anguina sp. and $R$. rathayi. Previous studies (1) determined that the best time to assess orchardgrass for Anguina sp. infestation was during flowering, when the Anguina galls were turning red. At this stage of development, florets could be easily spread out under a dissecting microscope with darkfield illumination to observe the reddishcolored galls under the lemma or palea. Fifty panicles, collected arbitrarily along each of two diagonal transects in each field, were assessed for Anguina sp. and $R$. rathayi. To avoid bias in selection of panicles, reproductive tillers were selected at random from the base of plants without examining the attached panicles. Galls of Anguina sp. or $R$. rathayi were counted on each panicle. The palea was removed from each suspect flower to verify presence of a gall. Galls of $R$. rathayi were characteristic yellow. $R$. rathayi that formed a gummosis was quantified on each panicle by visually estimating the proportion of the panicle affected. Flowers that were colonized by $R$. rathayi, beyond a discrete gall but not affecting more than one to several florets, were counted separately. In a previous study (7), the bacterial galls and yellow gummosis on orchardgrass in Oregon were found to be associated with $R$. rathayi.

In 2003 and 2004, a separate assessment of galls of $R$. rathayi and Anguina sp. was 
conducted. One hundred panicles were collected arbitrarily while walking along each of four transects in a $\mathrm{W}$ pattern in each field within 1 week of cutting. Tillers were selected at random from the base of plants without examining the attached panicles. Tillers without panicles were excluded from counts of total panicles. Panicles were air dried for 2 weeks, then hand threshed. The lemma and palea were removed using a scarifer, as previously described (1), and the number of galls of Anguina sp. and $R$. rathayi were visually counted under a dissecting microscope. Seed number per panicle was estimated from each transect by dividing the total seed (caryopses, without lemma or palea) by the total seed heads collected for that transect.

Yield loss estimates. Each gall of $A n$ guina sp. represents a single seed. Thus, yield loss from Anguina sp. equals the percentage of seed replaced by galls. A similar relationship applies to galls of $R$. rathayi. To estimate seed loss from galls or individual flowers infested with $R$. rathayi, counts of galls or infested flowers for each panicle at flowering were divided by the mean seed (caryopses) per panicle, determined from mature panicles collected just prior to harvest (as described above), and then multiplied by 100 to obtain the percentage. Because seed does not develop in the presence of the extensive bacterial growth, proportion of seed loss corresponds to the proportion of panicle engulfed in gummosis. All panicles with gummosis were examined under a dissecting microscope to determine if any seed were present in bacterially colonized flowers. The percentage of seed loss from gummosis for each panicle was determined by multiplying the percentage of each panicle with gummosis (visually estimated) by mean seed per panicle. Mean seed per panicle was determined from mature panicles collected within 1 week of cutting (as described above). Yield loss from $R$. rathayi was estimated from the sum of loss from gummosis, galls, and infested flowers.

Postharvest in-field estimates of $\mathbf{A n}$ guina sp. Following harvest, eight sites were chosen at random throughout each field. At each site, residues from a $0.25-\mathrm{m}^{2}$ quadrant were collected by hand and placed in paper bags. A vacuum was used to collect seed, galls, and other fine debris from the soil surface. Seed and galls were separated from residues through a series of seed-cleaning operations, including hand screens, air columns, and indent cylinders. These procedures were relatively gentle and not sufficient to fracture galls.

Statistical analysis. A $t$ test was used to compare sample means, based on meaningfully paired observations, as described by Steel and Torrie (13), and included mean values from each of the five fields. The test was used to determine whether percentage of panicles with galls, galls per panicle, or percentage of seed replaced by Anguina sp. or $R$. rathayi differed significantly between 2003 and 2004. In addition, the $t$ test was used to determine if Anguina sp. or $R$. rathayi galls per panicle, or percentage seed replaced by Anguina sp. or $R$. rathayi, differed significantly between flowering and maturity in 2003 or 2004 . All paired combinations were analyzed individually.

\section{RESULTS}

Pre- and postharvest estimates of Anguina sp. and $R$. rathayi. Mean seed per panicle ranged from 339 to 429 in 2003 and 405 to 479 in 2004 (Table 1). Percentage of panicles with Anguina sp. ranged from 9 to $24 \%$ (Table 1). Mean number of galls per panicle, based on panicles collected at flowering, ranged from 0.16 to 1.3. Percentage of seed replaced by $A n$ guina sp. (seed loss) per panicle, based on panicles collected at flowering, ranged from 0.03 to 0.38 (Table 1). Mean Anguina sp. galls per panicle collected near harvest ranged from 0.13 to 0.49 . Percentage of seed replaced by Anguina sp. (seed loss), based on panicles collected near harvest, ranged from 0.03 to 0.13 (Table 1). The number of galls per single panicle ranged from 0 to 29 . However, more than twice as many panicles had a single gall than two, and a relatively low frequency of panicles had eight or more galls (Fig. 1).

Percentage of panicles with $R$. rathayi, based on panicles collected at flowering, ranged from 3 to $27 \%$ (Table 2). R. rathayi galls per panicle, based on panicles collected at flowering, ranged from 0 to 0.32 (Table 2). The mean number of flowers per panicle with $R$. rathayi ranged from 0.03 to 1.36. Percentage of seed loss from $R$. rathayi ranged from 0.1 to 7.3 (Table 2). Mean number of $R$. rathayi galls per panicle at panicle maturity ranged from 0.02 to 0.45 (Table 2). There was no indication that bacterial infestation on one part of the panicle affected seed development on unaffected parts of the panicle.

Panicles were found to contain Anguina sp. or $R$. rathayi alone as well as in combi-

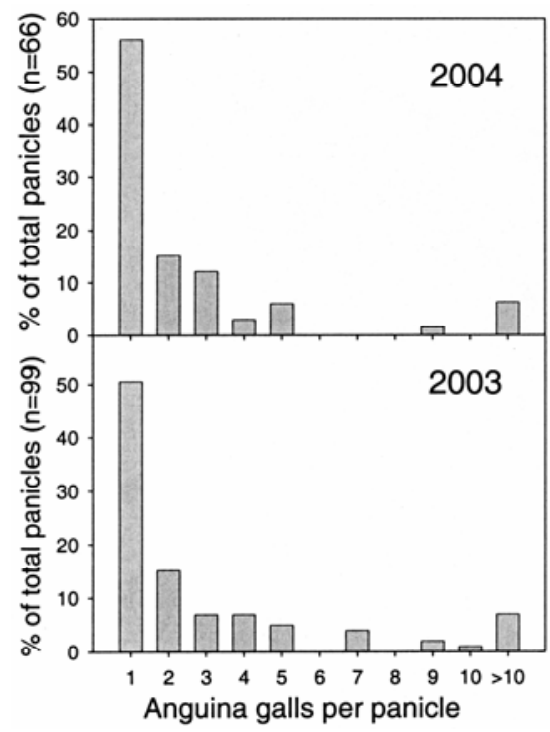

Fig. 1. Frequency of number of galls of Anguina sp. per orchardgrass panicle among five infested fields in 2003 and 2004.

Table 1. Orchard grass seed per panicle, percentage of panicles with galls of Anguina sp., Anguina sp. galls per panicle, and percentage of seed replaced by Anguina sp., assessed at flowering; and galls per panicle and percentage seed replaced by Anguina sp., assessed at orchardgrass maturity; in orchardgrass seed-production fields in Oregon in 2003 and 2004

\begin{tabular}{|c|c|c|c|c|c|c|c|c|c|c|c|c|}
\hline \multirow[b]{2}{*}{ Field } & \multicolumn{2}{|c|}{$\begin{array}{c}\text { Seed } \\
\text { per panicle }^{\mathrm{a}}\end{array}$} & \multicolumn{2}{|c|}{$\begin{array}{l}\text { Panicles with galls } \\
\text { at flowering }(\%)^{\mathbf{b}}\end{array}$} & \multicolumn{2}{|c|}{$\begin{array}{l}\text { Galls per panicle } \\
\text { at flowering }\end{array}$} & \multicolumn{2}{|c|}{$\begin{array}{c}\text { Seed replaced } \\
\text { at flowering }(\%)^{\mathrm{c}}\end{array}$} & \multicolumn{2}{|c|}{$\begin{array}{l}\text { Galls per panicle } \\
\text { at maturity }\end{array}$} & \multicolumn{2}{|c|}{$\begin{array}{c}\text { Seed replaced } \\
\text { at maturity }(\%)^{\mathrm{e}}\end{array}$} \\
\hline & 2003 & 2004 & 2003 & 2004 & 2003 & 2004 & 2003 & 2004 & 2003 & 2004 & 2003 & 2004 \\
\hline 1 & & & & & & & & & & & & \\
\hline 2 & & & & & & & & & & & & \\
\hline 3 & & & & & & & 0 & 0 & 8 & 6 & 0 & 02 \\
\hline 4 & $403 \pm 19$ & $405 \pm$ & 9 & 9 & $39 \pm 0.13$ & $0.42 \pm 0.37$ & $0.10 \pm 0.03$ & $0.10 \pm 0.09$ & $0.15 \pm 0.05$ & $0.20 \pm 0.07$ & $0.04 \pm 0.01$ & $0.05 \pm 0.01$ \\
\hline 5 & $373 \pm 59$ & $460 \pm 69$ & $17 \pm 4.2$ & $13 \pm 4.2$ & $0.36 \pm 0.03$ & $0.71 \pm 0.66$ & $0.10 \pm 0.01$ & $0.15 \pm 0.14$ & $0.19 \pm 0.07$ & $0.16 \pm 0.04$ & $0.05 \pm 0.03$ & $0.04 \pm 0.01$ \\
\hline
\end{tabular}

${ }^{a}$ Mean \pm standard deviation (SD) based on seed threshed from 100 panicles collected within 1 week of harvest from each of four transects from each field.

${ }^{\mathrm{b}}$ Mean \pm SD based on 50 panicles collected at flowering from each of two transects from each field.

${ }^{c}$ Mean \pm SD based on 50 panicles collected at flowering from each of two transects from each field. Calculated by dividing galls per panicle by mean seed per panicle from each of two transects.

${ }^{\mathrm{d}}$ Mean \pm SD based on four transects per field. Calculated by dividing total galls collected by total panicles per transect, based on 100 panicles collected within 1 week of harvest from each of four transects from each field.

${ }^{e}$ Mean \pm SD based on 100 panicles collected from each of four transects within 1 week of cutting. Calculated by dividing number of galls by number of galls + total seed and then multiplying by 100 to obtain percentage for each of four transects per field (100 panicles collected per transect within 1 week of cutting). 
nation. The proportion of panicles with Anguina sp. and $R$. rathayi in combination ranged from 10 to $40 \%$, depending on field and year (Fig. 2).

Mean values of percentage of panicles with Anguina sp. or $R$. rathayi at flowering, galls of Anguina sp. or R. rathayi per panicle, percentage of seed replaced by Anguina sp. or $R$. rathayi at flowering, Anguina sp. or $R$. rathayi galls per panicle at flowering, or seed per panicle were similar in 2003 and 2004. Significantly $(P$ $=0.05$ ) more Anguina sp. galls per panicle were found at flowering than at maturity in 2003 but not in 2004; similar results were found for percentage of panicles with $A n$ guina $\mathrm{sp}$. $R$. rathayi gall numbers did not differ significantly $(P=0.05)$ between flowering and maturity in either 2003 or 2004, although there was a suggestion of greater gall numbers at maturity in 2003 with a significance at $P=0.10$.

Mean density of Anguina sp. galls remaining within fields following harvest ranged from 2.4 to 18.4 per square meter (Table 3). Up to 40 galls per square meter were recovered.

\section{DISCUSSION}

The number of Anguina sp. galls per panicle ranged from 0 to 29 , with more than half the infested panicles containing only a single gall. A similar range of 1 to 58 Anguina sp. galls per infested panicle was observed in Polypogon monospeliensis in grazing lands in South Australia (2). A low level of Anguina sp. galls of about $0.1 \%$ by weight was reported among orchardgrass seed in the United Kingdom (12), consistent with previous reports from the United States (1). The low level of Anguina sp. found among seed heads corresponded to a low level of galls returned to the field during harvest. The population of galls remaining in the field following harvest ranged from 0 to 40 per square meter. Given a mean number of 1,200 nematode juveniles per gall (1), total population of nematodes would range from 0 to 48,000 per square meter. The level of $\mathrm{An}$ guina sp. infestation in orchardgrass differs significantly from the occurrence of $A$. agrostis in Oregon on bentgrass, in which seed loss from some fields reached 50 to $70 \%$ annually (5).

The genus Anguina is a known vector of Rathayibacter spp. However, the means of spread of $R$. rathayi within orchardgrass seed heads is not well known. Unlike other Anguina-Rathayibacter spp. associations, in which discrete galls are produced, gummosis from $R$. rathayi can engulf a single flower to an entire panicle. In the field, discrete heads typically are observed, with no indication of disease spread from infected to adjacent heads. Seed loss from $R$. rathayi is due primarily to bacterial gummosis. Much of the bacterial gummosis covering the seed heads is returned to the field with straw residue during harvest. No attempts were made to quantify the level of $R$. rathayi-contaminated residues returned to the field during harvest.

Although significant yield reductions (30 to 70\%) from Anguina-Rathayibacter spp. can occur in wheat (15), seed loss in orchardgrass in Oregon from Anguina sp. and $R$. rathayi did not exceed $8 \%$. In the cereal grains, grain quality is reduced by

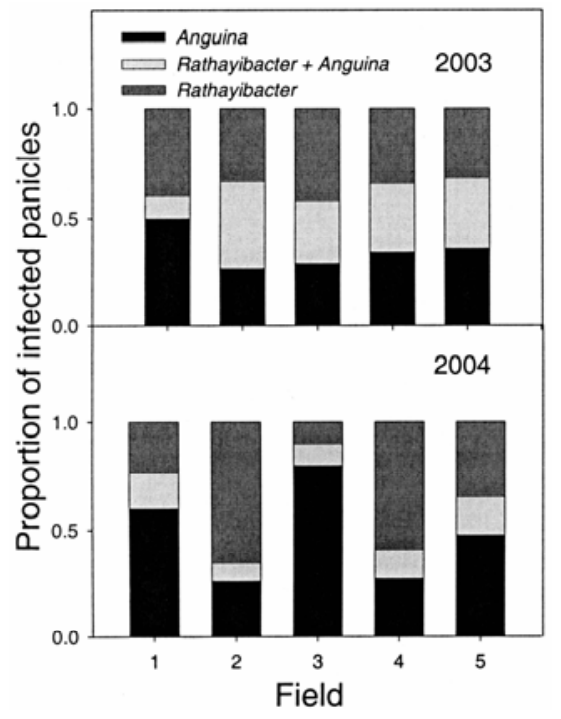

Fig. 2. Proportion of panicles with Rathayibacter rathayi only, both Anguina $\mathrm{sp}$. and $R$. rathayi, or Anguina sp. only, based on total panicles from five orchardgrass fields in 2003 and the same fields in 2004.
Anguina and Rathayibacter spp. (6). In orchardgrass, partially infected seed were not observed and seed appeared either healthy or were replaced or destroyed by Anguina sp. or $R$. rathayi.

Panicles of orchardgrass can be infected with Anguina sp. or $R$. rathayi alone or in combination. Anguina sp. is assumed to carry $R$. rathayi and occurrence of $R$. rathayi alone is likely when the nematodes are killed by bacterial proliferation. Significantly more galls of Anguina sp. per panicle occurred at flowering than at maturity in 2003. Considering significance at $P=0.10$, more $R$. rathayi galls were observed at maturity than at flowering in 2003. This suggests that $R$. rathayi colonization of Anguina sp. galls may continue beyond flowering.

Although some variation in the level of $R$. rathayi may occur, there is no indication from this or previous studies (1) that the level of Anguina sp. and $R$. rathayi is increasing in Oregon orchardgrass seedproduction fields. The population of $A n$ guina sp. within seed-production fields is likely to be limited by removal of galls during harvest and death of Anguina sp. from bacterial colonization. However, the population dynamics and increase of $A n$ guina sp. in commercial seed-production fields in the absence of $R$. rathayi has not been established.

Additional information is needed on the population dynamics of Anguina sp. and $R$. rathayi and the factors that regulate interaction of the two pathogens. Little is

Table 3. Estimates of number of galls of Anguina sp. in orchardgrass fields following harvest in 2004

\begin{tabular}{lcc}
\hline & \multicolumn{2}{c}{ Anguina sp. galls $/ \mathbf{m}^{\mathbf{2}}$} \\
\cline { 2 - 3 } Field & Mean \pm SD $^{\mathbf{a}}$ & Range \\
\hline 1 & $8.4 \pm 6.4$ & $0-20$ \\
2 & $9.2 \pm 9.2$ & $0-28$ \\
3 & $2.4 \pm 4.4$ & $0-12$ \\
4 & $18.4 \pm 19.6$ & $0-40$ \\
5 & $4.0 \pm 7.2$ & $0-20$ \\
\hline
\end{tabular}

${ }^{a}$ Mean and standard deviation (SD) based on examination of residues collected from $0.25-$ $\mathrm{m}^{2}$ areas at each of eight random sites from each field.

Table 2. Percentage of panicles with galls of Rathayibacter rathayi, galls per panicle, percentage of seed replaced by $R$. rathayi at flowering, and $R$. rathayi galls per panicle at maturity in orchardgrass seed-production fields in Oregon in 2003 and 2004

\begin{tabular}{|c|c|c|c|c|c|c|c|c|}
\hline \multirow[b]{2}{*}{ Field } & \multicolumn{2}{|c|}{$\begin{array}{l}\text { Panicles with } R . \text { rathayi } \\
\text { at flowering }(\%)^{\mathrm{a}}\end{array}$} & \multicolumn{2}{|c|}{$\begin{array}{c}R \text {. rathayi galls per panicle } \\
\text { at flowering }\end{array}$} & \multicolumn{2}{|c|}{$\begin{array}{l}\text { Seed replaced by } R \text {. rathayi } \\
\text { at flowering }(\%)^{\text {b }}\end{array}$} & \multicolumn{2}{|c|}{$\begin{array}{l}\text { R. rathayi galls per panicle } \\
\text { at maturity }\end{array}$} \\
\hline & 2003 & 2004 & 2003 & 2004 & 2003 & 2004 & 2003 & 2004 \\
\hline 1 & $19 \pm 1.4$ & $13 \pm 9.9$ & $0.17 \pm 0.11$ & $0.11 \pm 0.07$ & $2.8 \pm 0.5$ & $0.6 \pm 0.5$ & $0.27 \pm 0.14$ & $0.19 \pm 0.06$ \\
\hline 2 & $23 \pm 7.1$ & $18 \pm 8.5$ & $0.20 \pm 0.05$ & $0.03 \pm 0.04$ & $2.8 \pm 0.2$ & $3.2 \pm 1.3$ & $0.45 \pm 0.26$ & $0.04 \pm 0.03$ \\
\hline 3 & $27 \pm 12.7$ & $3 \pm 1.4$ & $0.32 \pm 0.10$ & $0.00 \pm 0.00$ & $7.3 \pm 3.8$ & $0.1 \pm 0.1$ & $0.38 \pm 0.23$ & $0.02 \pm 0.02$ \\
\hline 4 & $19 \pm 4.2$ & $18 \pm 8.5$ & $0.06 \pm 0.02$ & $0.11 \pm 0.16$ & $1.8 \pm 0.8$ & $1.0 \pm 1.3$ & $0.12 \pm 0.04$ & $0.07 \pm 0.4$ \\
\hline 5 & $16 \pm 1.8$ & $3 \pm 2.8$ & $0.07 \pm 0.01$ & $0.15 \pm 0.10$ & $3.3 \pm 1.0$ & $5.1 \pm 3.8$ & $0.11 \pm 0.02$ & $0.02 \pm 0.01$ \\
\hline
\end{tabular}

a Mean \pm standard deviation (SD) based on 50 panicles collected at flowering from each of two transects from each field.

${ }^{\mathrm{b}}$ Mean \pm SD based on 50 panicles collected at flowering from each of two transects from each field. Percentage of seed loss includes loss from gummosis, galls, and infested flowers.

${ }^{c}$ Mean \pm SD galls per panicle based on 100 panicles from each of four transects. Total galls from threshed seed were divided by 100 panicles to obtain galls per panicle for each transect. 
known of the longevity of $R$. rathayi in soils or of the movement of $R$. rathayi in contaminated, wind-blown residues. There currently are no management strategies in place for control of $R$. rathayi in orchardgrass. Presumably, elimination of Anguina sp. from a field would result in no $R$. rathayi infection, although this hypothesis remains untested.

\section{LITERATURE CITED}

1. Alderman, S. C., Bilsland, D. M., Griesbach, J. A., Milbrath, G. M., Schaad, N. W., and Postnikova, E. 2003. Use of a seed scarifier for detection and enumeration of galls of Anguina and Rathayibacter species in orchard grass seed. Plant Dis. 87:320-323.

2. Bertozzi, T., and McKay, A. C. 1995 . Incidence of Polypogon monspeliensis of Clavibacter toxicus and Anguina sp., the organisms associated with 'flood plain staggers' in South Australia. Aust. J. Exp. Agric. 35:567-569.

3. Bird, A. F., and Stynes, B. A. 1977. The mor- phology of a Corynebacterium sp. parasitic on annual rye grass. Phytopathology 67:828-830.

4. Courtney, W. D., and Howell, H. B. 1952. Investigations on the bent grass nematode, $A n$ guina agrostis (Steinbuch 1799) Filipjev 1936. Plant Dis. Rep. 36:75-83.

5. Jensen, H. J. 1961. Nematodes affecting Oregon agriculture. Oregon State University Agric. Exp. Stn. Bull. 579 .

6. Paruthi, I. J., Singh, M., and Grupta, D. C. 1987. Quantitative and qualitative losses in wheat grains due to 'earcockle' and 'tundu'. Seed Res. 15:83-86.

7. Postnikova, E., Agarkova, I., Riley, I. T., Alderman, S., Ocamb, C. M., Vidaver, A. K., and Schaad, N. W. 2004. Identification of Rathayibacter rathayi in Oregon and Maryland. (Abstr.) Phytopathology 94:S85.

8. Powers, T. O., Szalanski, A. L., Mullin, P. G., Harris, T. S., Bertozzi, T., and Griesbach, J. A. 2001. Identification of seed gall nematodes of agronomic and regulatory concern with PCRRFLP of ITS1. J. Nematol. 33:191-194.

9. Riley, I. T., and McKay, A. C. 1990. Specificity of the adhesion of some plant pathogenic microorganisms to the cuticle of nematodes in the genus Anguina (Nematoda: Anguinidae) Nematologica 36:90-103.

10. Riley, I. T., and McKay, A. C. 1991. Inoculation of Lolium rigidum with Clavibacter sp. the toxigenic bacteria associated with annual ryegrass toxicity. J. Appl. Bacteriol. 71:302306.

11. Smith, E. F. 1914. Bacteria in Relation to Plant Disease, Vol. 3. Carnegie Inst. Wash. Publ. 27. Press of Gibson Brothers, Washington, DC.

12. Southey, J. F. 1969. A gall forming nematode (Anguina sp.) parasitic on cocksfoot grass. Plant Pathol. 18:164-166.

13. Steel, G. D., and Torrie, J. H. 1980. Principles and Procedures of Statistics, a Biometrical Approach, Second Edition. McGraw-Hill, NY.

14. Stynes, B. A., Petterson, D. S., Lloyd, J. Payne, A. L., and Lanigan, G. W. 1979. The production of toxin in annual ryegrass, Lolium rigidum, infected with a nematode, Anguina sp. and Corynebacterium rathayi. Aust. J. Agric. Res. 30:201-209.

15. Thorne, G. 1961. Principles of Nematology. McGraw-Hill, NY. 